stream, but yet runs parallel to the island of Yesso, the water begins to deepen rapidly, and at the cast No, 24, or the third cast from the initial point of curve, a depth of 3,493 fathoms is found. Forty and eighty miles further on depths of 3,587 fathoms and 3,307 fathoms are reached; then the ocean bed or trough of the stream drops nearly a statute mile in the run to the next position, where the sinker is not detached until it has descended to the extraordinary depth of 4,340 fathoms.

"A good specimen of bottom soil was brought up from that great depth, and the Miller's Casella thermometer, No. 18,136, came up a perfect wreck. . . .

"The next six casts were made in over 4,000 fathoms water, the last two revealing depths of 4,4 I I fathoms and 4,655 fathoms respectively, and on both occasions the wire was lost. ....

"Sometimes the wire comes in much easier than at others, and cast No. 31 , made in 4, 120 fathoms, occupied only rh. $47 \mathrm{~m} .42 \mathrm{~s}$.

"The difference must be due to the varying action of the undercurrents upon the rod, specimen cup, and small lead, increasing or diminishing the resistance in hauling in, accordin's to the extent of curve from the perpendicular. ....

"The conditions under which all these deep casts werc made were eminently favourable. Believing that such deep water would be impracticable for cable purposes, I resolved to run inshore and sound back along the coast of the Kurile Islands to the position of cast No. 22, then to return and skirt those islands and the coast of Kamschatka as far as Cape Chipounsky, then passing over to the Alutian group.....

"If the time on the great circle route for the proposed cable has failed, at least for the present, the results of these soundings will be of interest and value to hydrographic science, as establishing the fact of depths in the sea hardly to be expected, in view of the numerous soundings made by her Majesty's steamship Challenger and this ship, over wide expanses of the Atlantic, Pacific, and Indian Oceans, and confirming the existence of a very deep trough under the Japan stream, similar to that cut by the Gulf Stream on our own coast. . . .

"As we passed by Sturup, of the Kurile group, dense volumes of smoke were seen rising out of a crater on the east end of the island."

\section{PROCEEDINGS OF THE FRENCH ASSOCIATION}

ON $\mathrm{N}$ Sunday the 23rd there was an excursion to Boulogne, to visit the steel-pen factory established by the Blanzy Company, and the Laboratory of Zoology, which Prof. Giard of Lille has organised by the seaside. On Monday many members paid a visit to Turcoing and Roubaix, two large manufacturing places in the vicinity of Lille, where the visitors were received with much courtesy; every workshop was eagerly thrown open for inspection.

At a general session held in the evening, M. Ménier, the large chocolate manufacturer who has realised an immense fortune in his trade, delivered a very appropriate lecture on the creation of wealth by science. No one has had so much practical experience on that subject in the society. M. Alglave, formerly a professor in the Academy of Douai, gave an impressive address on coalmining in Northern France. It was the first time that $M$. Alglave, who is very popular in Northern France, was allowed to deliver an address since he got into difficulties with the Government. His address created quite a sensation in the city.

On Tuesday there was a general excursion to Anzin coal-mines. A splendid luncheon was given to the visitors by the Anzin Company, in a large storehouse tastefully ormamented for the occasion with national flags and a trophy of all implements used by miners in their underground industry. M. Marsilly, the general director, proposed "The Visitors," in the name of the Council of Administration. M. Wurtz, in return, proposed "The Council and the illustrious President," whom he did not name, but who is no less a person than $M$. Thiers, at the mention of whose name enthusiastic cheers broke forth, interrupting $M$. Wurtz for more than five minutes. $M$. de Marsilly delivered a very long and able address, summarising all that the mining industry owed to science, and giving a few curious figures relating to his Company. It is 137 years old, and was the first French firm to import steam-engines from England. The number of hands is 15,000, and persons depending upon them 60,000. They are now constructing steam-engines, of 500 horse-power, for underground work. The society visited the Haveley pit, one of the forty belonging to the Company, whose concession covers about 100,000 acres, and is said to be worth more than $8,000,000$ sterling. On the same evening M. Gaston Tissander delivered an address on aërostation specially considered as to its meteorological uses. The lecture was illustrated by diagrams showing forms of clouds, optical phenomena connected with aërostation, \&c.

On Wednesday all the Sections were busy discussing the several communications, and held two sessions. M. Bergeron gave a most interesting address in the Engineering Department, on the boring of the tunnel between France and England. He said, upon authority, that the French Government had sent to Lord Derby a note asking him if he objected to the granting of the exclusive right for a number of years to a private Company. If the English Government does not raise any objection, the bill will be laid before the Versailles Assembly at the end of the present parliamentary holidays. Special provisions will be made for inundating the tunnel in case of war breaking out between the two countries. The holders of the concession can renounce their rights after spending $80,000 l$, in boring a gallery of exploration at least 1,100 ft. under the sea from low-water mark. The works are to begin on the French side as soon as the concession will have been granted. MM. Léon Say, Rothschild, André, \&c. are amongst the petitioners.

There was a very sharp discussion in the Anthropological Section on some theological points which had been raised.

In the evening Col. Laussedat delivered a lecture on optical military telegraphy. Almost all the officers of the garrison were present at the lecture, which was practically illustrated by various experiments.

In the morning of Thursday the business of the Sections was transacted as on the previous day, and at one o'clock a general meeting was held in the Hôtel de Ville under the presidency of M. Wurtz. Some modifications of the by-laws and regulations of the society were unanimously adopted, and the committee was instructed to ask from the Government a decree declaring the society of public utility. This is a step necessary, according to the French laws, to give societies the right of holding properties, accepting legacies, and obtaining parliamentary grants.

M. Wurtz had directed a message to the British Association asking them to send a delegation to take part in the Lille meeting. This could not be accomplished, owing to the distance, but it ended in an exchange of telegraphic courtesies between the two societies.

The British Association being our model, it is necessary for us to study its workings, in order to adapt them as far as we can to our French circumstances and scientific pecularities. Consequently, the committee was instructed not to name the opening day for the 1875 meeting before ascertaining whether it shall not coincide with the opening of the next session of the British Association.

Two cities were in competition for the 1875 meeting Clermont Ferrand, where the Puy de Dome Observatory 
will be inaugurated next year ; and Nantes. It was generally supposed that Clermont Ferrand would be selected, but Nantes had sent a special delegate with the power of offering the grant of a large sum of money. Clermont Ferrand is poor and has drained its exchequer in helping M. Alluard in his admirable work ; consequently Nantes was all but unanimously selected. The president for the Nantes meeting (1875) will be M. d'Eichtal, a gentleman of great fortune and influence, largely connected with the railway interest, and possessed of high scientific qualifications, having been educated at the Polytechnic School. The assembly appointed M. Faye, the astronomer, to be president of the 1876 meeting, but the town where it is to be held has not been decided on. The meeting was brought to a close by a banquet given at the Hôtel de Ville, by the Mayor of the city.

The number of the members of the Association is 800 ; it is an excess of 200 on the number of the Lyons meeting. The ladies are very few. Madame Thureau de Villeneuve, the wife of the secretary of the Société de Navigation Ardenne, was the only lady who delivered an address. This was in the section of Geography.

The Paris papers have published very short articles on the proceedings of the Association; none have shown so much interest as the Times, who sent a special reporter and published long telegrams on the work of the Sections.
Lille, August 29
W. DE FONVIELLE

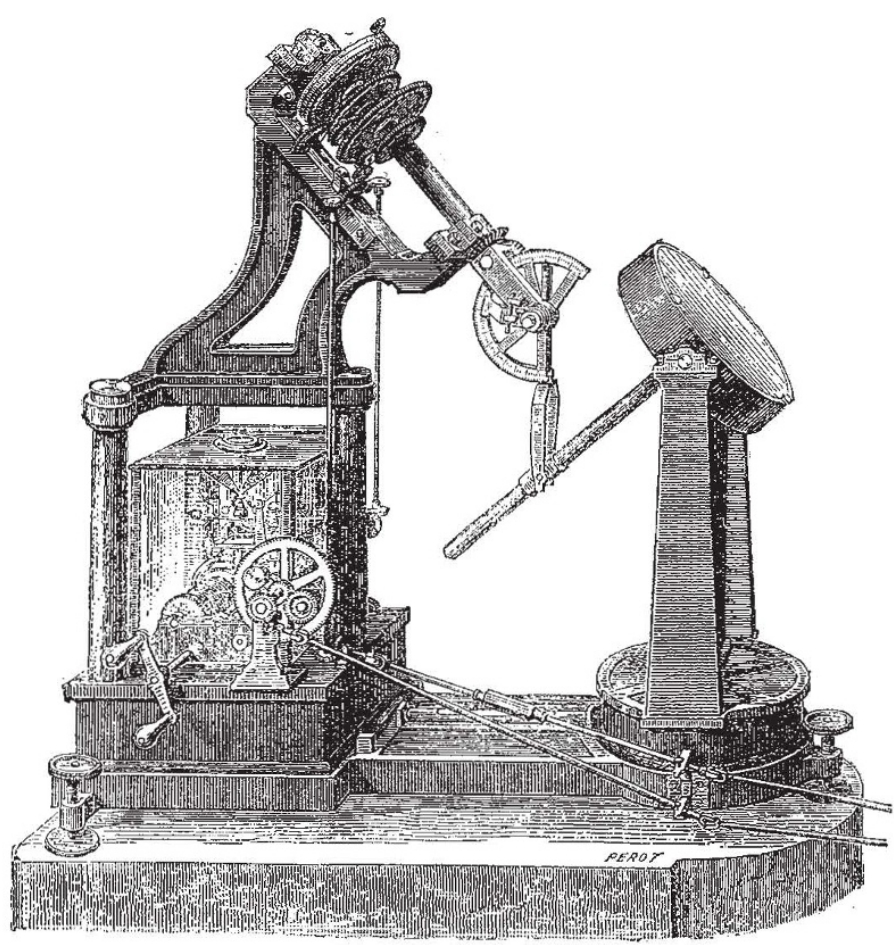

Fig. 1. - The Siderustat.

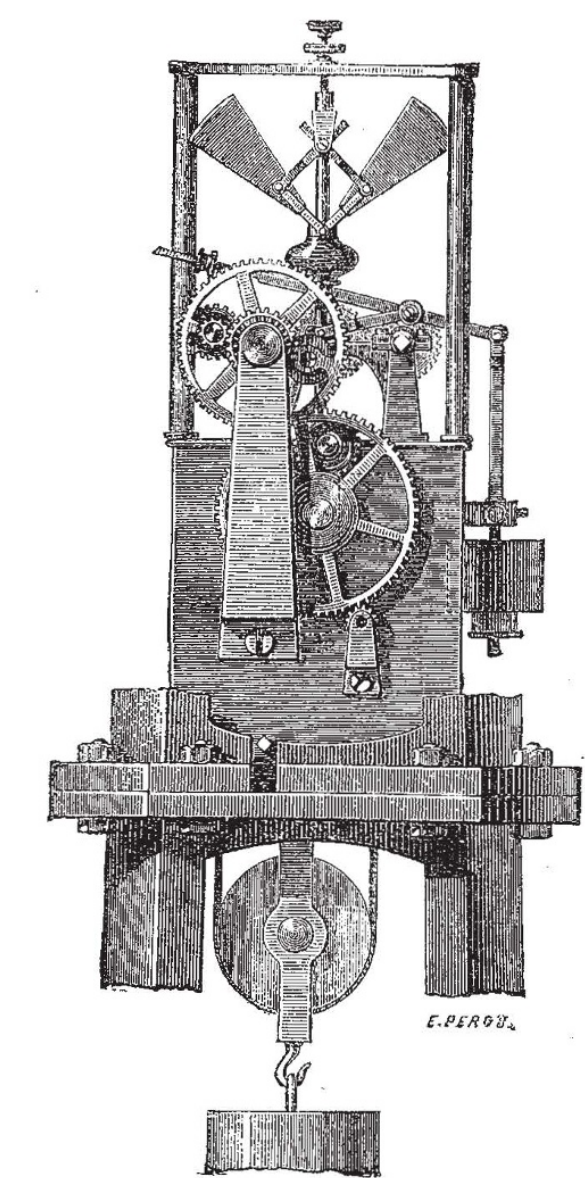

F1G. 2.-Clockwork movement, with isochronous regulator
THE SIDEROSTAT*

THERE is in use at the present moment in the Paris Observatory an instrument of a new construction, which is destined to play a large part in the Astronomy of the future. It is not too much to say that the new instrument will play as important a part in, and will be as essential to the new Astronomy, as the transit instrument plays in the Astronomy of position.

For this instrument in its present form we are indebted to the genius of Foucault, who also gave it its name, the Siderostat.

The use of the present instruments obliges the astronomer to change his position to follow the eye-piece, and consequently to observe frequently in uncomfortable positions. To escape this inconvenience the Germans have long employed the bent telescope, mexidian circles * In part translated from an article by M. A. Fraissenet, in La Nature. For the woodcuts we are indebted to the kindness of M. Gauthier-Villars. and theodolites. But the use of this arrangement is limited to small instruments, while it is precisely in the case of the largest instruments that it would be most useful.

Foucault, who died in the midst of his most inportant labours, wished in the latter years of his life to give to the equatorial the power of making the entire heavens pass before the observer without his having to disturb himself or to displace the instrument. A telescope fixed horizontally in an invariable position, before which a plane mirror brings successively the various points of the sky - such was the Siderostat in his mind, the idea in all probability having occurred to him from a singular employment of the heliostat by M. Laussedat in observations or the eclipse of 1860 . (See Fig. I.)

The instrument was constructed after the death of its inventor, by $\mathrm{M}$. Eichens, under the direction of the Commission charged with the carrying out and the publica- 